\title{
Circulating immune complexes in subacute infective endocarditis and post-streptococcal glomerulonephritis
}

\author{
IDRIS MOHAMMED, BARBARA M. ANSELL, E. J. HOLBOROW, AND \\ A. D. M. BRYCESON \\ From the Medical Research Council Rheumatism Unit, Canadian Red Cross Memorial Hospital, Taplow, \\ Maidenhead, Berkshire, and the Hospital for Tropical Diseases, St Pancras Way, London NWI
}

SUMMARY Two out of five patients with subacute infective endocarditis and two patients with poststreptococcal glomerulonephritis had large amounts of soluble circulating immune complexes in their sera. The three others with endocarditis had less severe disease and minimal evidence of circulating immune complexes. Low serum complement was also found in two of the cases.

Glomerulonephritis is a well recognised sequel to severe streptococcal infection (Heptinstall, 1966; Gutman et al., 1972; Keslin et al., 1973; BoultonJones et al., 1974). The nephritis varies in severity and duration, as does the outcome, and immune complex formation and deposition in the tissues may play an important part in this disease (Cordeiro et al., 1965; Cream and Turk, 1971; Boulton-Jones et al., 1974). The immunopathogenic mechanisms are not fully understood, but deposits of immunoglobulin and the third component of complement (C3) have been found in the glomeruli after an attack of post-streptococcal nephritis and also in subacute infective endocarditis. Severe cases of infective endocarditis may lead to renal damage, as BoultonJones et al. (1974) have shown. They provided evidence from immunofluorescent studies of renal biopsy specimens that renal damage after subacute infective endocarditis may be an immune complex phenomenon. We present here direct evidence of immune complex formation in patients with severe subacute endocarditis and post-streptococcal glomerulonephritis.

\section{Patients and methods}

The seven cases studied are summarised in Table 1 . It will be seen that two out of five patients with infective endocarditis had severe disease clinically, with renal failure and cardiac involvement as well. Patients 3 and 4 with post-streptococcal glom-

Received for publication 20 September 1976 erulonephritis had renal failure without cardiac lesions.

(1) DETECTION OF IMMUNE COMPLEXES

(a) Radiobioassay $(R B A)$

This is a competition assay in which ${ }^{125}$ I-labelled aggregated IgG competes with immune complexes for receptor sites on guinea-pig macrophages (Mohammed et al., 1977).

\section{(b) Clq-binding activity}

This method, based on the ability of ${ }^{125} \mathrm{I}-\mathrm{Clq}$ to bind immune complexes, was used as described by Zubler et al. (1976). The bound C1q is precipitated by $2.5 \%$ polyethylene glycol and the results are expressed as percentage of the added labelled $\mathrm{Clq}$ precipitated from the serum samples as compared with the total added C1q precipitated by $20 \%$ trichloroacetic acid (TCA).

\section{(c) Precipitation with polyethylene glycol (PEG)}

A modification of the method of Creighton et al. (1973) was used in which equal volumes of 1:5 sera and $8 \%$ PEG (mol.wt. 6000) are mixed and allowed to stand for 18 hours at $4{ }^{\circ} \mathrm{C}$. The resulting precipitates are washed in $4 \%$ PEG, redissolved in PBS, and the total protein in the samples is determined.

(2) SERUM IMMUNOGLOBULINS AND C3 These were measured as described by Mancini et al. (1965).

(3) ANTI-STREPTOCOCCAL ANTIBODIES

Sera in cases 1 and 3 were tested for anti-streptococcal 
Table 1 Summary of clinical findings in seven cases

\begin{tabular}{|c|c|c|c|c|c|}
\hline Case No. & History & Findings & Blood culture & Autoantibodies & Treatment \\
\hline 1 & $\begin{array}{l}\text { Syrian, male, } 55 \text {, fever, malaise, } \\
\text { night sweats, anorexia for } 18 \\
\text { months. SBE }\end{array}$ & $\begin{array}{l}\text { Pyrexial, finger clubbing, splinter } \\
\text { haemorrhages, vasculitis, mitral } \\
\text { and aortic incompetence. ESR } 65 \\
\text { mm } 1 \mathrm{~h}, \mathrm{Hb} 7.0 \mathrm{~g} / \mathrm{dl} \text {, blood urea } \\
12.6 \mathrm{mmol} / \mathrm{l}(70.6 \mathrm{mg} / 100 \mathrm{ml})\end{array}$ & $\begin{array}{l}\text { Streptococcus } \\
\text { viridans }\end{array}$ & $\begin{array}{l}\text { Smooth muscle } \\
\text { antibody titre } \\
\geqslant 1: 320\end{array}$ & $\begin{array}{l}\text { Blood transfusion, penicillin, } \\
\text { lincomycin, erythromycin } \\
\text { oral amoxycillin }+ \\
\text { probenecid }\end{array}$ \\
\hline 2 & $\begin{array}{l}\text { Male, } 56 \text {, fever, lassitude, night } \\
\text { sweats, weight loss. SBE }\end{array}$ & $\begin{array}{l}\text { Pyrexial, finger clubbing, } \\
\text { peripheral oedema, conjunctival } \\
\text { petechiae, linear fundal } \\
\text { haemorrhages, Roth's spots, } \\
\text { coarse tremor, limited shoulders, } \\
\text { bilateral knee effusions. } \\
\text { Proteinuria }+ \text {, ESR } 141 \mathrm{~mm} 1 \mathrm{~h} \text {, } \\
\text { Hb } 8 \cdot 8 \mathrm{~g} / \mathrm{dl}, \text { blood urea } 5 \cdot 1 \\
\text { mmol } 1(10 \cdot 7 \mathrm{mg} / 100 \mathrm{ml})\end{array}$ & $\begin{array}{l}\text { Streptococcus } \\
\text { viridans }\end{array}$ & $\begin{array}{l}\text { Antinuclear } \\
\text { antibody } \\
25 \text { units }\end{array}$ & $\begin{array}{l}\text { Blood transfusion, penicillin } \\
\text { and streptomycin, double } \\
\text { valve replacement }\end{array}$ \\
\hline 3 & $\begin{array}{l}\text { Male, } 17 \text {, sore throat followed by } \\
\text { vomiting, cough, haematuria, } \\
\text { oliguria, pedal oedema, and grand } \\
\text { mal fits. Nephritis }\end{array}$ & $\begin{array}{l}\text { Generalised macular rash, peri- } \\
\text { orbital oedema, BP } 180 / 120 \text {, } \\
\text { proteinuria }++. \text { Renal biopsy } \\
\text { consistent with post- } \\
\text { streptococcal glomerulo- } \\
\text { nephritis. ESR } 44 \mathrm{~mm} 1 \mathrm{~h}, \mathrm{Hb} \\
12 \cdot 8 \mathrm{~g} / \mathrm{dl} \text {, blood urea } 19 \cdot 2 \mathrm{mmol} / 1 \\
(101 \cdot 4 \mathrm{mg} / 100 \mathrm{ml})\end{array}$ & $\begin{array}{l}\text { Streptococcus } \\
\text { viridans }\end{array}$ & $\begin{array}{l}\text { Mitochondrial } \\
\text { antibody } \\
\text { positive }\end{array}$ & $\begin{array}{l}\text { Penicillin, valium, } \\
\text { phenobarbitone, } \\
\text { bendrofluazide (initially), and } \\
\text { clonidine }\end{array}$ \\
\hline 4 & $\begin{array}{l}\text { Female, } 38 \text {, sore throat, fever, } \\
\text { arthritis, and gross oedema after } \\
3 \text { weeks. Nephritis }\end{array}$ & $\begin{array}{l}\text { Erythema nodosum, proteinuria. } \\
\text { ASO titre } 1250 \text { units, ESR } 72 \mathrm{~mm} \\
1 \mathrm{~h} \mathrm{Hb} 10.6 \mathrm{~g} / \mathrm{dl} \text {, blood urea } 8.32 \\
\mathrm{mmol} / 1(50 \mathrm{mg} / 100 \mathrm{ml})\end{array}$ & Sterile & - & Penicillin \\
\hline 5 & $\begin{array}{l}\text { Male, } 31 \text {, sore throat, lassitude, } \\
\text { night sweats, history of } \\
\text { rheumatic fever, valvular heart } \\
\text { disease. SBE }\end{array}$ & $\begin{array}{l}\text { Pyrexial. ESR } 20 \mathrm{~mm} 1 \mathrm{~h}, \mathrm{Hb} 12 \cdot 7 \\
\text { g/dl, blood urea } 3 \cdot 8 \mathrm{mmol} / \mathrm{l} \\
(20 \cdot 3 \mathrm{mg} / 100 \mathrm{ml}), \text { ASO titre } 1250 \\
\text { units }\end{array}$ & $\begin{array}{l}\text { Streptococcus } \\
\text { viridans }\end{array}$ & - & Penicillin \\
\hline 6 & $\begin{array}{l}\text { Male, } 35 \text {, history similar to case } \\
\text { 5. SBE }\end{array}$ & $\begin{array}{l}\text { Pyrexial, ESR } 53 \mathrm{~mm} 1 \mathrm{~h} \text {, } \\
\mathrm{Hb} 11.4 \mathrm{~g} / \mathrm{dl} \text {, blood urea } 3 \cdot 3 \\
\mathrm{mmol} / 1(20 \mathrm{mg} / 100 \mathrm{ml}), \text { ASO } \\
\text { titre } 1250 \text { units }\end{array}$ & $\begin{array}{l}\text { Streptococcus } \\
\text { viridans }\end{array}$ & - & Penicillin \\
\hline 7 & $\begin{array}{l}\text { Male, 36, history similar to case } \\
5\end{array}$ & $\begin{array}{l}\text { Pyrexial. ESR } 66 \mathrm{~mm} 1 \mathrm{~h}, \mathrm{Hb} \\
15.5 \mathrm{~g} / \mathrm{dl} \text {, blood urea } 4 \cdot 2 \mathrm{mmol} / 1 \\
(20.5 \mathrm{mg} / 100 \mathrm{ml}), \text { ASO titre } 1250 \\
\text { units }\end{array}$ & $\begin{array}{l}\text { Streptococcus } \\
\text { viridans }\end{array}$ & - & Penicillin \\
\hline
\end{tabular}

antibodies (anti-DNase B and anti-M-associated protein (MAP)) at the Public Health Laboratory, Colindale.

\section{(4) AUTOANTIBODIES AND RHEUMATOID FACTOR}

Tests for autoantibodies and rheumatoid factor were performed on all the sera.

\section{Results}

Table 2 shows the amounts and types of complexes detected in each of the seven cases. In cases 1-4 levels of circulating immune complexes were high by RBA and C1q-binding and the PEG precipitates had a high protein content. These were patients with severe cardiac or renal complications, or both. In the milder cases (5-7) the levels of circulating complexes were lower, and were negative by radiobioassay in two of them. However, Clq-binding and precipitates with $4 \%$ polyethylene glycol were significantly raised in all. In cases 1 and 2 the patients had enhancing (EC) rather than inhibiting (IC) complexes. Both had positive rheumatoid factor tests (case $1,++$ latex; case 2, 1:16 DAT) and clinical evidence of cutaneous vasculitis.

The serum immunoglobulins and $\mathrm{C} 3$ are shown in Table 3. In cases 1 and 3 the levels of $\mathrm{C} 3$ were very low. The immunoglobulins were within the normal Caucasian range in all the patients except the patient in case 1 , who was a Syrian. Serum immunoglobulin levels tend to be higher in residents of the tropics (Mohammed et al., 1973).

The anti-DNase B and anti-MAP tests showed that there was little or no evidence of group A streptococcal infection in case 1 , whereas in case 3 there was evidence (not necessarily recent) of group A streptococcal infection. 
Table 2 Immune complex results

\begin{tabular}{|c|c|c|c|c|c|}
\hline \multirow[t]{2}{*}{ Case No. } & \multirow[t]{2}{*}{$\begin{array}{l}\text { Radiobioassay } \\
(\% \text { or } \% E)\end{array}$} & \multirow[t]{2}{*}{$\begin{array}{l}\text { Clq-binding activity } \\
(\%)\end{array}$} & $\begin{array}{l}\text { Precipitation with } 4 \% \text { polyethylene } \\
\text { glycol }\end{array}$ & \multirow[t]{2}{*}{$D A T$} & \multirow[t]{2}{*}{ Latex } \\
\hline & & & Total protein $(\mathrm{mg} \%)$ & & \\
\hline \multirow[t]{2}{*}{$\begin{array}{l}1 \\
2 \\
3 \\
4 \\
5 \\
6 \\
7\end{array}$} & $\begin{array}{rl}70 & \mathrm{E} \\
45 & \mathrm{E} \\
30 & \mathrm{I} \\
33 & \mathrm{I} \\
5 & \mathrm{I} \\
12 & \mathrm{I} \\
8 & \mathrm{E}\end{array}$ & $\begin{array}{l}81 \\
44 \\
58 \\
64 \\
35 \\
26 \\
21\end{array}$ & $\begin{array}{l}85 \cdot 0 \\
71 \cdot 5 \\
64 \cdot 5 \\
52 \cdot 5 \\
27 \cdot 5 \\
63 \cdot 0 \\
29 \cdot 0\end{array}$ & $\begin{array}{l}-\mathrm{ve} \\
1: 16 \\
-\mathrm{ve} \\
-\mathrm{ve} \\
\text {-ve } \\
-\mathrm{ve} \\
\text {-ve }\end{array}$ & $\begin{array}{l}++ \\
\text { ND } \\
\text {-ve } \\
\text {-ve } \\
\text {-ve } \\
\text {-ve } \\
\text {-ve }\end{array}$ \\
\hline & $\begin{aligned} \text { Normal } & <12 \mathrm{I} \\
& <5 \mathrm{E}\end{aligned}$ & Normal $<10$ & Normal $<0.02$ & & \\
\hline
\end{tabular}

$=\%$ inhibition $; \mathrm{E}=\%$ enhancement $; \mathrm{DAT}=$ differential agglutination titre; $\mathrm{ND}=$ not done.

Table 3 Serum immunoglobulins and C3

\begin{tabular}{lllll}
\hline Case No. & $I g G(g / l)$ & $I g A(g / l)$ & $I g M(g / l)$ & $C 3(g / l)$ \\
\hline 1 & 18.40 & 2.15 & 4.50 & 0.20 \\
2 & 17.80 & 1.94 & 1.97 & 0.63 \\
3 & 20.94 & 2.96 & 2.597 & 0.27 \\
4 & 19.04 & 1.82 & 2.23 & 1.03 \\
5 & 16.53 & 1.73 & 1.66 & 1.01 \\
6 & 17.44 & 1.64 & 2.15 & 1.11 \\
7 & 18.16 & 1.88 & 1.53 & 0.92 \\
Normal range & $6.00-16.00$ & $0.20-2.00$ & $0.20-3.00$ & $0.6-1.20$ \\
\hline
\end{tabular}

\section{Discussion}

Using three different methods we have found circulating immune complexes in five active cases of subacute infective endocarditis and in two of poststreptococcal glomerulonephritis. Two of the methods (radiobioassay and Clq-binding tests) are sensitive and specific for immune complexes, and our results provide a direct indication of immune complex formation in these patients. This is further persuasive evidence for a cause-and-effect relationship between immune complex deposition and the cardiac and renal complications of severe poststreptococcal infection.

In seropositive rheumatoid arthritis with vasculitis due to immune complex deposition serum immune complexes are present which tend to enhance rather than inhibit uptake of aggregated IgG by the macrophages in the radiobioassay test (Onyewotu et al., 1975), and a similar enhancement was seen with the sera from the two seropositive patients in the present study.

Evidence that immunological factors play an important pathogenetic role in the complications of subacute infective endocarditis was provided by Cordeiro et al. (1965). Hayward (1973) suggests that when high levels of circulating antibodies are attained during streptococcal infection they may lead to the formation of antigen-antibody complexes. He questions the traditional view that the 'flea-bitten' appearance of the kidney in endocarditis is solely due to infective emboli, and postulates that deposition of immune complexes is at least partly responsible. Cream and Turk (1971) also suggest that immune complexes are responsible for the so-called 'embolic' phenomena which occur classically in this disease.

More direct evidence of immune complex pathogenesis in the renal lesions complicating endocarditis was provided by Keslin et al. (1973) and BoultonJones et al. (1974), who by immunofluorescence have demonstrated immunoglobulins and $\mathbf{C} 3$ deposits in renal biopsy specimens. Some patients with subacute endocarditis develop autoantibodies as well as positive rheumatoid factor tests (Bacon et al., 1974), a finding which we have confirmed.

There is thus good evidence of several different kinds that immune complexes are responsible for renal damage in infective endocarditis. Cole (1975) describes a clinical diagnostic tetrad in this disease, which includes 'immune complex phenomena', and we are inclined to agree that petechial rash, Osler's nodes, Roth's spots, Janeway lesions, haematuria, retinal haemorrhage, vasculitis, splinter haemorrhages, and arthralgia result from immune complex deposition.

Post-streptococcal glomerulonephritis also has immunological sequelae. Two of our patients who developed isolated glomerulonephritis with renal failure had high levels of circulating immune complexes, and probably immune complex deposition in the kidneys was responsible for the renal damage. It has been suggested that certain strains of group A streptococci, particularly $M$ type 12 , are nephritogenic (Johnson and Stollerman, 1969) because they share antigenic determinants with the kidneys. One of our patients (case 3 ) had evidence of having had a group A infection, but even in this case it is equally possible that immune complexes involving strepto- 
coccal antigens were responsible for the renal damage. No evidence of group $A$ infection was found in case 1 , but notably the levels of circulating complexes in this patient remained high after three weeks' treatment. This raises the important question whether specific antibody had combined with streptococcal antigens to form the complexes or whether autoantibodies (that is antiglobulins or immunoconglutinins) were involved as well. The evidence suggests that both mechanisms might operate in the same patient, to a variable degree.

If immune complexes play an important immunopathogenic role in the complications of subacute infective endocarditis and in post-streptococcal glomerulonephritis treatment aimed at reducing their formation or concentration in addition to antibiotic therapy might be beneficial. Four of the patients described by Boulton-Jones et al. (1974) required dialysis for renal failure, and we suggest that early plasmaphoresis might obviate the need for this in patients with circulating immune complexes.

We thank the Medical Research Council for support, Dr Philip Johns for the ultracentrifugal analysis, Dr Jean Widdowson for streptococcal antibody determinations, and Mrs Bernadette Thompson for skilled assistance.

\section{References}

Bacon, P. A., Davidson, C., and Smith, B. (1974). Antibodies to candida and autoantibodies in sub-acute bacterial endocarditis. Quart. J. Med., 43, 537-550.

Boulton-Jones, J. M., Sissons, J. G. P., Evans, D. J., and Peters, D. K. (1974). Renal lesions of subacute infective endocarditis. Brit. med. J., 2, 11-14.

Cole, P. (1975). The enigma of infective endocarditis. Hospital Update, 1, 128-138.

Cordeiro, A., Costa, H., and Laginha, F. (1965). Immunologic phase of subacute bacterial endocarditis: a new concept and general considerations. Amer. J. Cardiol.,
$16,477-481$.

Cream, J. J., and Turk, J. L. (1971). A review of the evidence for immune-complex deposition as a cause of skin disease in man. Clin. Allergy, 1, 235-247.

Creighton, W. D., Lambert, P. H., and Miescher, P. A. (1973). Detection of antibodies and soluble antigenantibody complexes by precipitation with polyethylene glycol. J. Immunol., 111, 1219-1227.

Gutman, R. A., Striker, G. E., Gilliland, B. C., and Cutler, R. E. (1972). The immune complex glomerulonephritis of bacterial endocarditis. Medicine (Baltimore), 51, 1-25.

Hayward, G. W. (1973). Infective endocarditis: a changing disease-1. Brit. med. J., 2, 706-709.

Heptinstall, R. H. (ed.) (1966). Pathology of the Kidney, p. 330. Churchill, London.

Johnson, J. C. and Stollerman, G. H. (1969). Nephritogenic streptococci. Ann. Rev. Med., 20, 315-322.

Keslin, M. H., Messner, R. P., and Williams, R. C., Jr. (1973). Glomerulonephritis with subacute bacterial endocarditis. Arch. intern. Med., 132, 578-581.

Mancini, G., Carbonara, A. O., and Heremans, J. F. (1965). Immunochemical quantitation of antigens by single radial immunodiffusion. Int. J. Immunochem., 2, 235-254.

Mohammed, I., Thompson, B., and Holborow, E. J. (1977). Radiobioassay for immune complexes using macrophages. Ann. rheum. Dis., 36, Supplement 1, p. 49.

Mohammed, I., Tomkins, A. M., and Greenwood, B. M. (1973). Normal immunoglobulins in the tropics (Letter). Lancet, 1, 481.

Onyewotu, I. I., Johnson, P. M., Johnson, G. D., and Holborow, E. J. (1975). Enhanced uptake by guineapig macrophages of radio-iodinated human aggregated immunoglobulin $G$ in the presence of sera from rheumatoid patients with cutaneous vasculitis. Clin. exp. Immunol., 19, 267-280.

Zubler, R. H., Lange, G., Lambert, P. H., and Miescher, P. A. (1976). Detection of immune complexes in unheated sera by a modified ${ }^{125} \mathrm{I}-\mathrm{Clq}$ binding test: effect of heating on the binding of Clq by immune complexes and application of the test to systemic lupus erythematosus. J. Immunol., 116, 232-235. 